ОСОБЛИВОСТІ ЗАСТОСУВАННЯ ІНТЕРАКТИВНИХ МЕТОДІВ НАВЧАННЯ У ПРОЦЕСІ ПІДГОТОВКИ МАЙБУТНІХ ФАХІВЦІВ ОПЕРАТИВНО-РЯТУВАЛЬНОЇ СЛУЖБИ ЦИВІЛЬНОГО ЗАХИСТУ

\title{
PECULIARITIES OF APPLICATION OF INTERACTIVE METHODS OF LEARNING DURING TRAINING OF FUTURE SPECIALISTS OF RAPID RESPONSE SERVICE OF CIVIL PROTECTION SERVICE
}

УДК 37

DOI https://doi.org/10.32843/2663-

6085/2020/22-2.19

\section{Кришталь Т.М.,}

докт. екон. наук, доцент, завідувач кафедри управління у сорері цивільного захисту Черкаського інституту пожежної безпеки імені Героїв Чорнобиля Національного університету цивільного захисту України Панімаш ю.В., канд. пед. наук, доцент кафедри управління у сорері цивільного захисту Черкаського інституту пожежної безпеки імені Героїв Чорнобиля

Національного університету цивільного захисту України

Горбаченко Ю.М.,

канд. іст. наук, доцент,

доцент каредри управління

у ссрері цивільного захисту

Черкаського інституту пожежної безпеки імені Героїв Чорнобиля

Національного університету

цивільного захисту України
У статті розкрито поняття «інтеракція», розглянуто інтерактивні методи навчання. Наведено приклади застосування інтеракції під час підготовки майбутніх фрахівців оперативно-рятувальної служби цивільного захисту України. Проаналізовано послідовність організації та проведення інтерактивних методів навчання для досягнення комунікативної компетенції курсантів. Зазначено, що важливо організовувати навчання у дружній психологічній атмоссрері. Визначено та розкрито три етапи застосування інтерактивних методів навчання. Інтерактивні методи вимагають якісної підготовки викладачів для успішної організації навчального процесу. Встановлено, що етапність процесу самореалізації майбутніх фрахівців оперативно-рятувальної служби цивільного захисту відкриває певні можливості застосування інтерактивного навчання та зосередження уваги на конкретних його аспектах у прочесі професійної підготовки. Для першого етапу запропоновано інтерактивні вправи: «Займи позицію», «Спільна угода», «Коло ідей», «Мозковий штурм», «Метод виклику», «Приховані скарби», «Очікування», дискусія за методом «Квадро», «Лінія цінностей», «Таємні таланти», «Шкала думок», «Мікрофрон». Для другого етапу запропоновано застосування ситуативних вправ - кейс-стаді, ділових і рольових ігор. Визначено, що для застосування ситуаційного моделювання варто враховувати пізнавальну, суспільну, аналітичну, управлінську складові частини. На третьому етапі запропоновано використовувати тренінги, які сприятимуть розкриттю особистісного потенціалу курсантів, розвитку їхніх управлінських якостей, аналітичних умінь $i$ навичок. Описано тренінгове заняття «Стилі керівництва», котре включає в себе міні-лекції, тести, рольові ігри, домашне завдання. Проаналізовано типологію стилів управління. Встановлено, що ефрективний навчальний процес може відбутися тільки за умови поступової активної взаємодіі курсанта і викладача, які $є$ рівнозначними суб'єктами процесу та мають спільну ідею щодо їхніх знань і вмінь.

Ключові слова: інтеракція, метод проектів, рольова гра, дискусія, метод «саse studys.

The article researches the notion of interaction and studies interactive methods of learning. Several examples of the application of interaction during the training process of the future specialists of the rapid response service of the Civil Protection Service of Ukraine are given. The sequence of organizing and conducting of the interactive methods of learning in order to reach communicative competence of cadets is analyzed. It is noted that it is significant to teach in a psychologically friendly surrounding. Three stages of application of interactive methods of learning are determined and described. It is highlighted that interactive methods of learning require a high-quality training of teachers to successfully organize educational process. It is found out that the stages of the process of the self-realization of the future specialists of the rapid response service of the Civil Protection Service of Ukraine open the door for the application of interactive learning and focusing attention on its definite aspects in the process of their professional training. The following interactive exercises are offered to be used during the first stage: "Take a position", "Common agreement", "Circle of Ideas", "Brainstorming", "Method of Call", "Hidden Treasures", "Waiting", a discussion based on the method of "Quadro", "Line of Values", "Secret Talents", "Scale of Thoughts", "Microphone". Situational exercises are offered to be used during the second stage: case-study, role and business simulation games. It is determined that cognitive, social, analytical and managerial components should be taken into consideration when applying situational modeling. As for the third stage, it is suggested to use trainings which help realize cadets' personal potential and develop their managerial and analytical skills.

Key words: interaction, project method, role play, discussion, case-study.
Постановка проблеми в загальному вигляді. Сучасний освітній простір України відзначається активним пошуком шляхів модернізації процесу навчання у закладах вищої освіти. Це дозволяє вирішити нагальні потреби у підготовці спеціаліста нового типу, який відповідатиме вимогам сучасного суспільства та буде здатний шукати рішення шляхом співпраці з колегами.

У зв'язку з цим актуальним $є$ вивчення можливості застосування інтерактивних методів навчання під час навчального процесу у профрільних закладах вищої освіти ДСНС України.
Аналіз останніх досліджень і публікацій. Проблема застосування інтерактивних методів у навчальному процесі була в центрі уваги таких вітчизняних і російських науковців, як Н. Баліцька, О. Євтух, Н. Коломієць, І. Куришева, Л. Пироженко, О. Пометун, Г. П'ятакова, О. Сіроштан, О. Січкарук та ін.

Виклад основного матеріалу. Слово «інтеракція» (від англ. interaction - взаємодія, inter - взаємний, act - діяти) виникло в соціології та соціальній психології (К. Левин, Дж. Мід, Дж. Морено, К. Фопель, Т. Шибутані та ін.). 
I. Куришева під інтерактивними методами навчання розуміє «способи» організації активної, продуктивної взаємодії учнів між собою, з учителем, із різними джерелами інорормації, а також із комп'ютером у формі навчальних, ділових, рольових ігор, дискусій, виконання проектів, аналізу конкретних ситуацій, за якої відбувається освоєння нового досвіду й одержання нових знань, надається можливість для самореалізації учнів [1, с. 12]. На думку Н. Коломієць, інтерактивними вважаються такі методи навчання, які реалізуються завдяки активній взаємодії учнів і дають змогу на основі внеску кожного з них у спільну справу отримувати нові знання, організувати спільну діяльність, ідучи від окремої взаємодії двох-трьох осіб до широкої співпраці класного колективу [2].

Суть інтерактивного навчання у тому, що навчальний процес відбувається за умови постійної, активної взаємодії всіх учасників. Організація інтерактивного навчання передбачає моделювання життєвих ситуацій, використання рольових ігор, вирішення проблеми на основі аналізу обставин відповідної ситуації. Воно ефективно сприяє фрормуванню навичок і вмінь, виробленню цінностей, створенню атмосорери співробітництва, взаємодії [3].

На нашу думку, для досягнення високих результатів у навчанні та засвоєнні необхідної інфрормації інтерактивні методи навчання слід застосовувати у три етапи. На першому етапі, який розпочинається на першому курсі навчання у профрільних закладах вищої освіти ДСНС України, основну увагу слід звертати на реалізацію таких педагогічних умов, як: розвиток ціннісних орієнтацій і аксіосфери курсантів; мотивоване їх залучення до інтеракції; розробка навчально-методичного забезпечення інтерактивного навчання курсантів. На цьому етапі курсантам слід пропонувати цікаві інтерактивні вправи, що сприяють розвитку позитивної мотивації. Організація навчально-методичного забезпечення для проведення інтерактивного навчання курсантів повинна передбачати вибір аудиторій, де учасники фрормувального експерименту могли би працювати у групах, у колі, вільно пересуватися, активно взаємодіяти між собою тощо; підготовку технічних засобів навчання (комп'ютера, мультимедійної дошки, відеоапаратури, фротоапарата, магнітофрона, фрліп-чарта тощо); забезпечення заняття необхідними предметами для підвищення інтересу курсантів до їх проведення та наочності (вогнегасниками, мотузками, карабінами, макетами об'єктів, манекенами, пожежними стволами, пожежними рукавами, олівцями, фрарбами, ватманом тощо) та розмноження роздаткових матеріалів для кожного учасника.

Модератором у процесі реалізації першого етапу застосування інтерактивних методів навчання повинен бути сам експериментатор, котрий заохочуватиме учасників інтерактивного навчання до співпраці, ставитиме цікаві та мотивуючі питання, вибудовуватиме обговорення певних проблем.

Учасникам слід дотримуватися загальних правил спілкування у процесі інтерактивного навчання, а саме:

- орієнтуватися на певну мету;

- вміти слухати;

- уникати загальних фрраз, чітко фрормулювати думки;

- бути активним у бесіді;

- приймати конструктивну критику.

Під час першого етапу вважаємо за необхідне використовувати такі інтерактивні вправи: «Займи позицію», «Спільна угода», «Коло ідей», «Мозковий штурм», «Метод виклику», «Приховані скарби», «Очікування», дискусію за методом «Квадро», «Лінія цінностей», «Таємні таланти», «Шкала думок», «Мікрофрон» тощо. Особливу увагу слід приділити вправі «Мозковий штурм», за допомогою якої відбувається спільне визначення і визначення пріоритетів діяльності, відкриваються нові можливості для підготовки та подальшого проведення занять. Цей інтерактивний метод сприяє стимуляції групи курсантів до швидкого генерування великої кількості ідей, не вимагає спеціальної підготовки, дозволяє легко розв'язувати будь-які проблеми.

Другий етап застосування інтерактивних методів у процесі інтерактивного навчання розпочинається на другому курсі здобуття освітнього ступеня і триває протягом третього року навчання. Він передбачає реалізацію таких педагогічних умов: організації освітнього процесу як засвоєння системних знань, умінь і навичок управлінської діяльності на основі творчої взаємодії та співпраці викладачів і курсантів, створення комсрортних умов для навчання; використання у процесі навчання курсантів інтерактивних технологій, методів, технік, засобів навчання. На цьому етапі варто застосовувати методики, що сприяють наближенню теорії навчання до практики майбутньої професійної діяльності. Основними інтерактивними методами, які слід використовувати, є ситуаційні вправи - кейс-стаді, ділові та рольові ігри.

У процесі застосування ситуаційного моделювання варто враховувати, що повинен бути комплексний опис створеної ситуації, в якому умовно виділено такі підструктури: пізнавальну, управлінську, суспільну, аналітичну, мотиваційну. Пізнавальна складова частина ситуаційної вправи передбачає наявність фрактографічних елементів, які розширюють, доповнюють знання курсантів певними конкретними персоніфікованими прикладами, взятими із життя. Управлінська складова частина ситуаційної вправи повинна спрямовуватися на використання управлінських команд, що використовуються у практиці діяльності опера- 
тивно-рятувальної служби, змушувати оперувати точною, професійною мовою, приймати управлінські рішення. Суспільна складова частина ситуаційної вправи відображає можливість групового обміну думками й зіставлення різних думок курсантів у процесі інтерактивного навчання. Аналітична складова частина у структурі ситуаційної вправи передбачає системний аналіз ситуації як активного методу навчання. Мотиваційна складова частина ситуаційної вправи вимагає створення цікавої дидактичної ситуації, що стимулює і залучає курсантів до пошуку шляхів її вирішення. Як приклад ситуативних вправ, які варто застосувати на другому етапі підготовки майбутніх фрахівців оперативно-рятувальної служби цивільного захисту, можна навести вправу «Технологія сім кроків».

мета вправи: технологія використовується із метою пошуку і розв'язання складних управлінських рішень. Вправа допомагає «дисциплінувати» думки членів команди й виявляти найоптимальніший спосіб вирішення управлінських проблем.

Хід вправи. Команда учасників ділиться на групи. Робота проводиться покроково.

Крок перший - «Туманна ситуація». Спільно виявити важливу проблему управлінської діяльності оперативно-рятувальних підрозділів. Кожна група виявляла проблему окремо.

Крок другий - «Пошук фрактів». Довести за допомогою командного обговорення та певних фрактів необхідність і важливість розв'язання цієї проблеми.

Крок третій - «Визначення проблеми». Визначити найважливіші чинники та ризики проблеми, оскільки правильне фрормулювання проблеми сприяє її розумінню всіма членами команди.

Крок четвертий - «Створення поля ідей». Завдання - знайти якомога більше ідей, способів вирішення визначеної проблеми.

Крок п'ятий - «Оцінка та відбір». Завдання визначити найконструктивніші ідеї розв'язання проблеми й оцінити реалістичність кожної з них.

Крок шостий - «Образ рішення». Завдання продумати сценарійпрактичної реалізації найбільш реалістичної ідеї.

Крок сьомий - «Складання плану дій». Завдання - скласти конкретний і чіткий план дій, спрямований на практичну реалізацію цієї управлінської проблеми.

У ході організації та застосування ділових ігор у навчальному процесі закладів вищої освіти ДСНС України слід дотримуватися таких основних принципів: 1. Ділова навчальна гра $€$ дидактичним засобом розвитку творчого (теоретичного і практичного) професійного мислення. Це досягається конструюванням (на етапі розробки) та реалізацією (у процесі гри) системи проблемних ситуацій і пізнавальних задач. 2. Предметним змістом гри виступає імітація конкретних умов і динаміки діяльності фрахівців оперативно-рятувальної служби цивільного захисту. 3. Ділова навчальна гра за цільовою спрямованістю $є$ двоплановою діяльністю, яка сприяє досягненню як ігрових, так і педагогічних (навчальних) цілей із домінуючою роллю останніх. 4. Ділова гра конструюється та проводиться як спільна діяльність учасників навчального процесу в ході постановки професійно важливих цілей і їх досягнення шляхом підготовки та прийняття відповідних індивідуальних і групових рішень. Виконання учасниками ігрових правил, підпорядкування «нормам» професійних відносин і дій стають обов'язковими умовами розгортання повноцінної гри за умов, наближених до практики. 5. Основним засобом включення учасників у спільну діяльність та одночасно способом створення і розв'язання ігрових проблемних ситуацій є двостороннє (діалог) і багатостороннє спілкування (мультилог), що забезпечує можливість вироблення індивідуальних і групових рішень, досягнення проміжних і кінцевих результатів гри.

Реалізація цих принципів дозволяє усвідомлено конструювати та застосовувати ділові ігри як засіб навчання фрахівців, фрормування у них як особистісних, так і ділових якостей, зокрема профресійної та комунікативної компетентностей [4].

Третій етап триває під час четвертого року навчання у профрільних ЗВО ДСНС України. Він сприяє самореалізації суб'єктів освітнього процесу шляхом розкриття їхнього особистісного потенціалу та прояву управлінських якостей в інтерактивному навчанні, розвитку аналітичних умінь і навичок, корекції власної поведінки у процесі управлінської діяльності. На цьому етапі слід використовувати тренінги, що сприятимуть розкриттю особистісного потенціалу курсантів, розвитку їхніх управлінських якостей, аналітичнихумінь і навичок.

Цікавим прикладом тренінгу є заняття «Стилі керівництва». Він включає:

1. Метод незавершених речень (із подальшим груповим обговоренням): «Управлінська діяльність...», «Стиль керівництва...».

2. Міні-лекція із використанням мультимедійної презентації: «Сучасні стилі керівництва». Успіх керування будь-яким колективом визначається не лише окремими рисами керівника, але і його стилем управління як системою способів, методів і форм впливу керівника на підлеглих, що постійно повторюються, забезпечують успішну реалізацію функцій управління. У вузькому розумінні стиль управління науковці розуміють як особливості спілкування керівника з людьми.

Найбільш відомою є типологія стилів, запропонована у 30-х рр. американським психологом німецького походження Куртом Левітом. Згідно 3 цією типологією визначають три типи керівників: демократів; автократів; лібералів. Отже, демократичний стиль характеризується прийняттям 
рішень із участю колективу, тобто підлеглі - це не просто виконавці чужих рішень, а люди, котрі мають власні цінності, керівництво враховує їхні інтереси. Авторитарний стиль (директивний чи диктаторський) характеризується ухваленням одноосібних рішень у вигляді директив, які не підлягають обговоренню. Ліберальний стиль (натуральний, анархічний, нейтральний або формальний), по суті, означає втрату керівництва, відхід від активного управління.

3. Групова дискусія: «Визначте й охарактеризуйте специфрічні особливості стилів управлінської діяльності».

4. Рольова гра «Стилі управлінської діяльності». Мета: ознайомитися зі стилями управління. Хід гри: кожна команда розігрує запропоновану ситуацію відповідно до обраного стилю управлінської діяльності.

5. Тест «Стиль спілкування та керівництва».

6. Підведення підсумків. Вправа «я хочу сказати своєму сусіду...». Вправа «Дерево підсумків». Курсантам пропонується зробити аналіз сьогоднішнього заняття.

7. Домашнє завдання (після проведення заняття): пройдіть тест «Психологічна готовність виконавця до переходу на управлінську роботу».

Висновки. Отже, ефективний навчальний процес може відбутися тільки за умови поступової активної взаємодії курсанта і викладача, які є рівнозначними суб'єктами процесу та мають спільну ідею щодо їхніх знань і вмінь. Інтерактивні методи навчання сприяють оптимізації навчального процесу. Вони покликані привести в дію механізми мотивації та підвищити ефективність навчання, забезпечити кращу профресійну підготовку. До переваг використання інтерактивних методів у процесі навчання курсантів у просрільних закладах вищої освіти ДСНС України можна віднести максимальне наближення до реальних умов професійної діяльності, широку самостійність курсантів, прийняття рішень в умовах творчого змагання та розвиток навичок швидкого прийняття рішень під час надзвичайних ситуацій, сприяння розвитку організаційних та управлінських навичок.

Безперечно, матеріал статті не вичерпує всіх аспектів проблеми, що розглядається. Перспективи подальших досліджень вбачаємо в розробці методичних рекомендацій щодо підвищення ефрективності підготовки майбутніх фрахівців оперативно-рятувальної служби цивільного захисту у процесі інтерактивного навчання.

\section{БІБЛІОГРАФІЧНИЙ СПИСОК:}

1. Курышева И.В. Интерактивные методы обучения как фрактор самореализации старшеклассников в учебной деятельности при изучении естественнонаучных дисциплин : авторефр. дис. ... канд. пед. наук : 13.00.01 / Нижегор. гос. пед. ун-т. Нижний Новгород, 2010. С. 12.

2. Коломієць Н.А. Дидактичні засади застосування інтерактивних методів навчання молодших школярів : автореф. дис. ... канд. пед. наук : 13.00.09. Нац. пед. ун-т ім. М.П. Драгоманова.

3. Пометун О.І., Пироженок Л.В. Сучасний урок. Інтерактивні технології навчання : науково-методичний посібник / за ред. О.І. Пометун. Київ : Видавництво А.С.К., 2004. 192 с.

4. Максименко С.Д., Філоненко М.М. Педагогіка вищої медичної освіти : підручник. Київ : Центр навчальної літератури, 2014. 288 с. 